\title{
Club Health - Perspectivas globales, nuevas direcciones
}

\section{Club Health: Global Perspectives, New Directions}

Fiona Measham*; TAMmy Anderson**;

PHIL HADFIELD ${ }^{\star \star *}$
* Profesora titular de Criminología. Universidad de Lancaster (GB).

** Departamento de Sociología y Justicia Criminal. Universidad de

Delaware (EE.UU.)

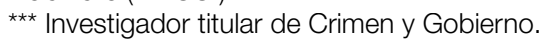

Universidad de Leeds (GB).

Enviar correspondencia a:

Fiona Measham. Lancaster University. F.Measham@lancaster.ac.uk

\section{RESUMEN}

Este número presenta las perspectivas de los editores invitados en esta colección resumiendo parte de los temas generales de una selección de trabajos presentados en el Congreso Club Health 2008, celebrado en Ibiza (España). Se da especial importancia al valor de los enfoques comparativos en los estudios sobre clubs, la cultura juvenil y el consumo de sustancias, para que los investigadores, los políticos y los médicos tengan una nueva visión de la interrelación de los factores locales y globales que definen las culturas del club, los ambientes nocturnos y los estilos de vida individuales. Al contextualizar las investigaciones en este número, se subrayan temas y cuestiones importantes que potenciarán los estudios sobre los clubs como un campo de trabajo interdisciplinar en el futuro.

Palabras clave: estudios sobre clubs, comparativos, economía del ocio nocturno, drogas, consumo de sustancias, culturas de club, música, jóvenes, reducción de daños.

\section{ABSTRACT}

This editorial presents the views of the guest editors of this collection in summarising some of the general themes arising from a selection of papers presented at the 2008 Club Health Conference in Ibiza, Spain. Particular emphasis is placed upon the value of comparative approaches to club studies, youth culture and substance use so that researchers, policy-makers, and practitioners can gain new understanding of the interplay of local and global factors which shape club cultures, nightlife scenes, and individual lifestyles. By contextualizing the studies in this volume, the editorial outlines important themes and issues which will help promote Club Studies as an interdisciplinary field of endeavour well into the future.

Key words: Club Studies, comparative, night-time economy, drugs, substance use, club cultures, music, young people, harm reduction. 
$\mathrm{E}$ el mundo hay pocos lugares tan apropiados para un Congreso de Club Health como la isla española de Ibiza. Históricamente, la isla ha sido una colonia musical de hippies y de pioneros de la marcha (ravers), además de un centro turístico de verano para muchos europeos. En la actualidad, Ibiza acoge fundamentalmente a dos tipos de turistas. Los primeros son familias europeas que acuden a la isla en los meses de verano para disfrutar de espectaculares playas de arena blanca flanqueadas por precipicios y de las cristalinas aguas del mar bajo un cielo cálido y luminoso. Consumen cultura española e historia ibicenca en la ciudad de Ibiza y en Dalt Villa (la ciudad amurallada). Los grupos promotores de fiestas y los funcionarios del gobierno quieren atraer a más familias y a profesionales mayores a la isla, ofreciéndoles un ocio ajeno a las discotecas. Por ejemplo, en Dalt Villa hay un festival anual de jazz en julio y es sede del Festival Internacional de Cine Gay y Lésbico.

El segundo grupo de turistas, más numeroso, es el de discotequeros y entusiastas de la "música dance electrónica» de toda Europa y de otros continentes. Con sus vacaciones han financiado el crecimiento de la isla, sus infraestructuras y casi todo lo que alli hay. Ibiza ha reinado como capital de este tipo de músico desde los primeros tiempos del rave y ocupa uno de los primeros lugares del ocio discotequero europeo o clubbing?.

Los turistas discotequeros de lbiza proceden de numerosos países, lo cual nos indica que el clubbing es una actividad cultural fundamental para los jóvenes y los adultos jóvenes de todo el mundo ${ }^{2}$. Sin embargo, cada vez hay más estudios que demuestran que dicha actividad cultural tiene consecuencias para la salud pública y social. Por tanto, era oportuno que los investigadores, los médicos y los interesados en el campo de los estudios sobre el club se reuniesen en el Congreso de Club Health celebrado en Ibiza en 2008 para compartir trabajos e ideas sobre esta actividad global.

Tras dos décadas de culturas de club y casi dos décadas de investigación e intervenciones con discotequeros o clubbers, el fenómeno del clubbing sigue interesando a los investigadores, médicos y políticos de todo el planeta. La vitalidad del mundo de las discotecas y de los estudios sobre el mismo se refleja en este estudio, desde perspectivas locales, nacionales y globales. La John Moores University de Liverpool, Gran Bretaña, ha celebrado cinco congresos bianuales de Club Health desde su inicio en el año 2000, abordando una amplia gama de temas que afectan a la salud de los jóvenes en los entornos de ocio nocturno, como el consumo de sustancias, la salud sexual, la conducta antisocial provocada por el alcohol, la gestión y diseño de los ambientes nocturnos, la formación de los empleados de las discotecas, y el turismo internacional de las mismas. En 2008 el congreso de Club Health, organizado por Irefrea (www.irefrea.org) y el Consell de lbiza, en colaboración con la John Moores University de Liverpool (www.cph.org.uk), contó con más 100 ponencias y presentaciones de pósters sobre el extenso conjunto de aspectos que afectan a los jóvenes en los entornos nocturnos, reuniendo a especialistas de numerosos campos. El desafío radica en contextualizar los detalladísimos y variados estudios de micronivel y los análisis nacionales presentados
$\mathrm{F}$ ew places in the world provide as good a location for a conference on Club Health as does the island of Ibiza in Spain. Historically, the island has functioned as a music colony for hippies and pioneering ravers as well as a beach resort for Europeans on summer holiday. Presently, Ibiza hosts two main types of tourists. The first are European families who come to the island during the summer months for spectacular white sandy beaches flanked by cliffs and crystal blue waters under warm, sunny skies. They consume Spanish culture and native lbizan history in Ibiza town and Dalt Villa (the walled city). Increasingly, party promotional groups and local government officials attempt to lure more families and older professionals to the island for nonclubbing leisure. In Dalt Villa, for example, there is an annual jazz festival in July and the International Gay and Lesbian Film Festival stops there as well.

The second and larger group of tourists is 'electronic dance music' clubbers and enthusiasts from all over Europe and further afield. Their holidays to Ibiza have financed the island's growth, its infrastructure and most aspects of life there. Ibiza has reigned as an EDM capital since the early days of rave and remains one of the top spots for European clubbing".

Since lbiza's clubbing tourists hail from numerous countries, they remind us that clubbing is a critical cultural activity for youth and young adults across the globe ${ }^{2}$. However, a growing body of research has shown that such cultural activity is accompanied by social and public health consequences. It seems fitting then, that academics, practitioners and other stakeholders in the field of Club Studies would gather at the 2008 Club Health conference in Ibiza to disseminate their work and thoughts about this global activity.

After two decades of dance club cultures and nearly two decades of research and interventions with clubbers, the clubbing phenomenon remains an activity inspiring interest from academics, practitioners and policy makers across the globe. The vibrancy of both clubbing and Club Studies is reflected in this special issue, from the local and the national to global perspectives. Liverpool John Moores University in the UK has held five biennial Club Health conferences since its inception in 2000, focusing on a wide range of issues that affect the health of young people in nightlife settings, including substance use, sexual health, alcoholrelated antisocial behaviour, management and design of nightlife settings, training for club staff, and international dance tourism. In 2008, the Club Health conference, hosted by Irefrea (www.irefrea.org) and Consell de Ibiza, alongside Liverpool John Moores University, featured more than 100 papers and poster presentations on the wide range of issues that affect young people in nightlife settings, bringing together individuals from a wide range of fields. The challenge is to contextualise the many detailed and varied micro level studies and national overviews presented at the conference 
en el Congreso dentro de un marco internacional e interdisciplinar $^{3}$, para lograr que los diferentes organismos entiendan las cuestiones del ocio nocturno y colaboren, en consecuencia, para crear ambientes nocturnos más seguros, positivos y no discriminatorios. Tanto el Congreso Club Health como este número específico de la revista Adicciones pretenden facilitar el desarrollo de esas relaciones globales y confirmar los estudios sobre el contexto recreativo nocturno como un campo de investigación sólido.

Dada la expansión global de los estudios sobre el club, hay al menos dos cuestiones que merecen nuestra atención: ¿En qué se distingue la actividad de frecuentar discotecas y qué distingue a los clientes que van a ellas? Cada uno de los artículos de este número especial contempla de un modo $u$ otro ambas cuestiones. En todo el mundo hay un estrecho vínculo entre las relaciones sociales que establecen los adultos jóvenes en los locales de ocio nocturno y una serie de conductas arriesgadas como pueden ser el consumo excesivo de alcohol, el tabaco, el consumo de drogas ilegales o las prácticas sexuales de riesgo, características de los ambientes discotequeros que surgen siempre en los diversos estudios en relación con los jóvenes que acuden a dichos locales en paises muy diferentes como Portugal ${ }^{4}$ o los ingleses de vacaciones en España ${ }^{5}$. Esto indica que los clubbers del siglo XXI, como los ravers anteriores, son un grupo sociodemográfico definido e identificable, "comprometidos con el clubbing" ${ }^{6}$ y con prolíficos aunque distintos historiales de consumo de drogas los fines de semana 7 ; por otro lado, el clubbing es una fase característica en las vidas de muchos jóvenes ${ }^{8}$. Por tanto, otra cuestión en relación con la planificación y la práctica es cómo abordar este conjunto de conductas; hasta qué punto hay que promover la salud, la reducción de daños y la prevención del delito entre determinados grupos, y las consecuencias de dicha iniciativa.

Entre este conjunto de actividades de riesgo relacionadas con las discotecas, a los investigadores y médicos les preocupa especialmente la relación entre el clubbing y el consumo de drogas ilegales. Desde una perspectiva de salud pública y de justicia criminal, el consumo de drogas entre los clubbers es una de las prioridades esenciales y resulta extraordinariamente prolífico en comparación con el de la población general de edad similar ${ }^{4,9}$.Algunos investigadores se centran en aspectos más amplios de la experiencia del clubbing en el que se consume droga, como el disfrute de la música, nociones de colectivismo social, identidades y desigualdades, y entienden que estos aspectos del clubbing no relacionados con las drogas se han dejado de lado ${ }^{8,10}$; otros se centran de forma más directa en el consumo de drogas porque opinan que es la parte olvidada de la ecuación. A pesar de estas diferentes perspectivas, un rasgo unificador es la continua búsqueda de tipologias locales, pero internacionalmente significativas, de clubbing, clientes y consumo de drogas en discotecas. Es evidente que tanto las variaciones nacionales como las conexiones culturales globales hacen que los posibles impactos en la salud física y mental, la seguridad y el bienestar de los clubbers sean una prioridad absoluta a corto plazo ${ }^{5}$ y a largo plazo $^{11}$. within an international and transdisciplinary framework ${ }^{3}$, to help promote better interagency understanding of nightlife issues and hence better partnership working to create safer, more positive and inclusive nightlife environments. Both the Club Health conference and this special issue aim to facilitate the development of these global connections and confirm Club Studies as an established field of endeavour.

Given the expanse of Club Studies globally, at least two questions merit attention: how distinct is the activity of attending clubs and how distinct are the people who go to clubs? Each of the papers in this special issue contributes in some way towards addressing these two questions. Across the world, there is a strong association between young adults socialising in night-time leisure venues and a cluster of risk-taking behaviours including heavy drinking, smoking, illegal drug use and sexual risk taking, features of clubbing scenes found repeatedly in studies of club-goers in many different countries as Portugal ${ }^{4}$ or British holiday makers in Spain ${ }^{5}$. This suggests that twenty first century clubbers, like earlier ravers, may be a distinct and identifiable sociodemographic group with a 'commitment to clubbing'6 and with prolific yet distinct weekend drug repertoires", as well as clubbing being a distinct phase in some young people's lives $^{8}$. A further question for policy and practice, then, is how to address this cluster of behaviours, the extent to which specific groups should be targeted in terms of health promotion, harm reduction or crime prevention, and the implications of such targeting.

Of this cluster of risk-taking activities related to clubgoing, a central concern for academics and practitioners is the relationship between clubbing and illicit drug use in particular. From both a public health and criminal justice perspective, clubbers' drug use is one of the main priorities and continues to be exceptionally prolific compared with the general population of similar age ${ }^{4,9}$. Some researchers may focus on broader aspects of the clubbing experience in which drug-taking occurs, such as musical appreciation, understandings of social collectivism, identities or inequalities, and feel that these non drug-related aspects of clubbing have been somewhat neglected ${ }^{8,10}$; others focus more directly on drug-taking and feel this has been the neglected side of the equation. Yet despite these differing emphases, a unifying feature is the ongoing pursuit of internationally meaningful yet locally relevant typologies of clubbing, club-goers and club drug use. What is apparent is that both the national variations and global cultural connections alike make the potential impacts on physical and mental health, safety and wellbeing of clubbers a high priority in both the short term ${ }^{5}$ and longer term ${ }^{11}$.

It is both challenging and vital to understand the essence of clubbing and its broader impact on health, crime, leisure and pleasure. Yet understanding the essence of clubbing involves considerable trans-disciplinary efforts to push the 
Es vital, aunque difícil, comprender la esencia del clubbing y su impacto extensor en la salud, la delincuencia, el ocio y el placer. Comprender la esencia del clubbing requiere un considerable esfuerzo interdisciplinar para ir más allá de la relación entre discotecas y drogas, como se ve en el estudio de Forsyth ${ }^{9}$, sobre la omisión del papel de la música en el mundo de las discotecas y la economía nocturna. En vez de cuestionar el clubbing y a los que participan en ello, algunos de los artículos de este número ${ }^{5,9}$ demuestran como las discotecas dentro del conjunto de la economía nocturna puede suponer que la cultura del club se asocia a un menor riesgo de consumo de alcohol, conductas sexuales peligrosas, agresión y violencia en comparación con locales de ocio más populistas y orientados al consumo de alcohol. La música dance electrónica juega un papel tanto en la reducción de problemas o daños de los clientes como en promover "politicas blandas", puesto que en la programación y selección de la música funcionan procesos informales de exclusión y manipulación estratégica del comportamiento que realizan perfiles étnicos, seleccionan a los clientes y forman élites dentro de la economía del ocio nocturno. La cuestión de la formación de élites y de la diferenciación social es fundamental en los estudios sobre el club y en la investigación más amplia sobre la economía del ocio nocturno y la vida nocturna en general. Los estudios ${ }^{8,10}$ que utilizan métodos etnográficos sostenidos han empezado a resquebrajar la capa superficial de homogeneidad de muchas opiniones profanas y de los medios de comunicación con respecto a las culturas del club, las pautas y preferencias de consumo de sustancias y nociones de inclusión y exclusión. Existen cuestiones de estatus y ámbitos de identidad transversal de cultura, diferenciación, gustos, clase socio-económica y etnicidad que hacen que los clubs y sus clientes se vean inmersos en complejas redes de selección social. Estos procesos son más visibles dentro de determinados ambientes de ocio local, pero adoptan características cada vez más globales en las principales capitales del mundo y en emporios del clubbing como lbiza. Por tanto, existe una tensión entre los aspectos locales y regionales de la cultura del club -que incluyen preferencias musicales y de sustancias, formas de delincuencia y desviación, y matices estilísticos- y un alcance cada vez más global del imaginario del club, sus manifestaciones y la interrelación de los propios clubbers, sobre todo los de los paises desarrollados.

Es evidente que la plataforma Club Health tiene implicaciones importantes cara a las intervenciones ${ }^{12}$ y las políticas - de salud pública y justicia criminal-, pero aparte de minimizar los daños y optimizar los beneficios, estos artículos contribuyen a un trabajo emergente que reconoce el impacto tanto positivo como negativo del clubbing, incluyendo la consideración del concepto de "bienestar" y la forma en que el clubbing y las drogas de club influyen en el bienestar de los individuos y, a través de ellos, en la sociedad en conjunto. Esto se ve de forma clara en la contribución económica del turismo de club en lbiza, la importancia cultural de lbiza dentro de las culturas de club, y el significado de los mercados de drogas ilegales y el consumo de drogas para los residentes y trabajadores de la isla de Ibiza, de España, Europa y otros lugares. boundaries beyond the club-drug relationship, exemplified in the work of Forsyth ${ }^{9}$, in relation to neglect of the role of music in clubbing and the night-time economy. Indeed, rather than problematising clubbing and clubbers, several papers here suggest that a consideration of dance clubs within the broader night-time economy shows how club cultures may be related to a decreased risk of involvement in drinking, sexual risk taking, aggression and violence in comparison with more alcohol-oriented and populist leisure venues ${ }^{5,9}$. Electronic dance music may play a role in both the reduction of problems or harms to participants, and also in 'soft policing', as informal processes of exclusion and strategic behavioural manipulation operate through music profiling and programming, ethnic profiling, customer selection and the formation of elites within the night-time economy. This issue of elite formation and social differentiation is emerging as a central theme in club studies and research on the wider night-time economy and forms of nightlife. Studies ${ }^{8,10}$ utilising sustained ethnographic methods have begun to pierce the surface veneer of homogeneity prevalent in many lay and media discourses with regard to club cultures, substance use patterns and preferences, and notions of inclusion and exclusion. Issues of status and identity crosscut spheres of culture, distinction, taste, socio-economic class and ethnicity, with clubs and their customers being involved in complex webs of social sorting. Whilst these processes are most observable within distinct local leisure scenes they also assume increasingly global characteristics in the world's major cities and clubbing destinations such as Ibiza. There appears to be a tension, therefore, between notions of the locally and regionally distinct aspects of club culture - which can include music and substance preferences, forms of crime and deviance and stylistic nuances - and the increasing global reach of clubland imagery, discourses and the inter-mingling of clubbers themselves particularly those from developed nations.

Clearly Club Health has enormous implications for policy and practice interventions ${ }^{12}$ - public health and criminal justice- but beyond minimising the harms and maximising the pleasures, these papers also contribute to an emergent endeavour which recognises the positive as well as negative impact of clubbing, including a consideration of the concept of 'wellbeing' and how clubbing and club drugs may impact on the wellbeing of both the individuals involved and wider society. This is evident in relation to the economic contribution of clubbing tourism to lbiza; the cultural importance of Ibiza to club cultures and also the significance of illegal drug markets and drug use to residents and workers on the island of Ibiza, in Spain, Europe and beyond. 
1. Anderson T. Rave Culture: The Alteration and Decline of a Music Scene. Philadelphia, USA: Temple University Press; 2009.

2. Hunt G, Moloney M, Evans K. Youth, Drugs and Nightlife. New York: Routledge; 2009.

3. Hadfield $P$, editor. Nightlife and Crime: Social Order and Governance in International Perspective. Oxford: Oxford University Press; 2009.

4. Lomba L, Apóstolo J, Mendes, F. Drugs and alcohol consumption and sexual behaviours in night recreational settings in Portugal. Adicciones 2009; 21: 309-325.

5. Hughes K, Bellis MA, Whelan G, Calafat A, Juan M, Blay N. Alcohol, drugs, sex and violence: health risks and consequences in young British holidaymakers to the Balearics. Adicciones 2009; 21: 265-277.

6. Moore K. A Commitment to Clubbing. Peace Review: A J Social Justice 2004; 16:459-65.

7. Measham F, Moore K. Repertoires of Distinction: Exploring Patterns of Weekend Polydrug Use within Local Leisure Scenes across the English Night Time Economy. Criminology and Criminal Justice 2009; 9: 437-64.

8. Anderson TL, Kavanaugh PR, Rapp L, Daly K. Variations in Clubbers' Substance Use by Individual and Scene-Level Factors. Adicciones 2009; 21: 289-308.

9. Forsyth AJM. Lager, lager shouting': The role of music and DJs in nightclub disorder control. Adicciones 2009; 21: 327-345.

10. Measham F, Hadfield P. Everything Starts with an 'E': Exclusion, ethnicity and elite formation in contemporary English clubland. Adicciones 2009; 21: 363-386.

11. Silins $E$, Copeland J, Dillon P. Hábitos y daños del consumo de fármacos entre los consumidores de éxtasis en Australia. Adicciones 2009; 21, 347-362.

12. Calafat $A$, Juan $M$, Duch MA. Preventive interventions in nightlife: a review. Adicciones 2009; 21, 387-414. 
